Brazilian Journal of political Economy, vol. 29, nº 2 (114), pp. 212-227, April-June/2009

\title{
States and Economic Development
}

\section{ATUL KOHLI*}

Today the Washington Consensus on development lies in tatters. The recent history of the developing world has been unkind to the core claim that a nation that opens its economy and keeps government's role to a minimum invariably experiences rapid economic growth. The evidence against this claim is strong: the developing world as a whole grew faster during the era of state intervention and import substitution (1950-1980) than in the more recent era of structural adjustment (1990-2005); and the recent economic performance of both Latin America and SubSaharan Africa—regions that truly embraced neoliberalism—has lagged well behind that of many Asian economies, which have instead pursued judicial and unorthodox combinations of state intervention and economic openness. As scholars and policy makers reconstruct alternatives to the Washington Consensus on development, it is important to underline that prudent and effective state intervention and selective integration with the global economy have been responsible for development success in the past; they are also likely to remain the recipes for upward mobility in the global economy in the future."

Key-words: states and industrialization; growth in developing countries; South Korea, India, Nigeria and Brazil; state types and state capacity.

JEL Classification: O38; O43; O57, P51.

Today the Washington Consensus on development lies in tatters. The recent history of the developing world has been unkind to the core claim that a nation that opens its economy and keeps government's role to a minimum invariably experiences rapid economic growth. The evidence against this claim is strong: the

\footnotetext{
* Princeton University, e-mail: kohli@Princeton.edu. An earlier version of this paper was presented to the world wide meeting of The Ford Foundation's unit on Governance and Civil Society in São Paulo, Brazil, November, 1-2, 2007. Submitted: November 2007; Approved: January 2007.
} 
developing world as a whole grew faster during the era of state intervention and import substitution (1950-1980) than in the more recent era of structural adjustment (say, 1990-2005); and the recent economic performance of both Latin America and Sub-Saharan Africa - regions that truly embraced neoliberalism - has lagged well behind that of such Asian economies as China, India, and Vietnam, which have instead pursued judicial and unorthodox combinations of state intervention and economic openness (Amsden, 2007). No wonder that the World Bank itself (2005) recently announced the death of the Washington Consensus, offered an overt mea culpa, and wondered aloud, where do we go next? While the disintegration of the Washington Consensus raises serious "sociology of knowledge" questions about who pushed these ideas, why, who benefited, and who should now be held responsible, my focus in this essay is more strictly on intellectual issues of logic and evidence that help us understand the political and economic conditions of development success and failure.

The Washington Consensus on development rested on two prior scholarly claims: first, the experience of the developing world with state-led economic growth (say, from 1950 to 1980) was a disaster; and second, that "globalization" (say, post-OPEC, especially following the second hike in oil prices in 1981) changed the rules of the economic game so significantly that states had few alternatives but to embrace all out economic openness. As scholars and policy makers reconstruct alternatives to the Washington Consensus on development, it is important to reevaluate both of these major claims. How exactly does one evaluate the role of the state in development in the post-second World War period? Has "globalization" really changed the global political economy so fundamentally that all out openness is the only alternative for developing countries? These are critical, controversial, and huge scholarly issues. In what follows, I synthesize some recent scholarship to argue that the answer to both of these questions is more complex than was assumed by the proponents of the Washington Consensus. I draw on my own recent book (Kohli, 2004 or SDD) to revisit the role of the state in economic development, and on a variety of other sources, including Stiglitz (2002) and World Bank (2005) to question the claim that there is no alternative to all out openness. The argument below instead is that prudent and effective state intervention and selective integration with the global economy have been responsible for development success in the past; they are also likely to remain the recipes for upward mobility in the global economy in the future.

\section{STATE-DIRECTED DEVELOPMENT}

My recent book $S D D$ was a strong rebuttal of the claim that state intervention in the developing world was responsible for development failures. Building on the 
works of such scholars as Chalmers Johnson (1982), Robert Wade (1990), Alice Amsden (1989), and Peter Evans (1995), I claim in SDD that both successful and failed attempts at industrialization in the developing world are best understood with reference to the economic role of more or less effective states. Well constructed "developmental" states, such as in East Asia, especially South Korea, facilitated rapid industrialization via both import substitution and export promotion. By contrast, many states in sub-Saharan Africa, especially Nigeria, which were poorly constructed and personalistic, failed at both import substitution and export promotion. In between these extreme types of states can be found a variety of more "mixed' states - such as in Brazil and India - that produced some notable successes, but also some pronounced failures. It is my argument in $S D D$ then that the way state power is organized and used has decisively influenced rates and patterns of industrialization in the global periphery.

State Types: In SDD I identified three ideal-typical historical patterns of how state authority is organized and used in the developing world: neopatrimonial states; cohesive-capitalist states; and fragmented-multiclass states. In addition to centralized and coercive control over a territory, a defining characteristic of all modern states is a well-established public arena that is both normatively and organizationally distinguishable from private interests and pursuits. Unfortunately, for a variety of historical reasons, this distinction between the public and the private realms was never well established in a number of developing country states, especially African states. As a result, a number of distorted states emerged with weakly centralized and barely legitimate authority structures, personalistic leaders unconstrained by norms or institutions, and bureaucracies of poor quality. These states are labeled here as neopatrimonial because, despite the façade of a modern state, public officeholders tend to treat public resources as their personal patrimony. These are therefore not really modern, rational-legal states. Whether they are organized as a nominal democracy or as a dictatorship, state-led development under the auspices of neopatrimonial states has often resulted in disaster, mainly because both public goals and capacities to pursue specific tasks in these settings have repeatedly been undermined by personal and narrow group interests. Of the cases I analyzed, Nigeria best exemplified this ideal-typical tendency.

Cohesive-capitalist and fragmented-multiclass states are two of the other ideal-typical states to be found in the contemporary developing world. The more effective modern rational-legal states in the developing world tend to vary mainly along two dimensions: cohesion of state authority and the state's class commitments. The cohesive-capitalist states, sometimes called developmental states, are situated opposite neopatrimonial states on the political effectiveness continuum. These states are characterized by cohesive politics, that is, by centralized and purposive authority structures that often penetrate deep into the society. For a variety of historical reasons these states have tended to equate rapid economic growth with national security and thus defined it as a priority. In their pursuit of rapid growth, 
cohesive-capitalist states have carved out a number of identifiable links with society's major economic groups and devised efficacious political instruments. Especially notable among the social links is a close alliance with producer or capitalist groups. An important corollary of this political arrangement is a tight control over labor. The main political instrument of these states is, of course, a competent bureaucracy. Since a narrow elite alliance between the state and capital is difficult to hold together, politics within these units has often been repressive and authoritarian, with leaders often using ideological mobilization (e.g., nationalism and/or anticommunism) to win acceptance in the society. Cohesive-capitalist states in developing countries, such as in South Korea under Park Chung Hee and in Brazil during both Estado Novo and the military dictatorship, have proved to be relatively successful agents of deliberate state-led industrialization.

In between the two extremes of political effectiveness defined by neopatrimonial states on the one end and cohesive-capitalist states on the other end lie fragmented-multiclass states. Unlike neopatrimonial states, fragmented-multiclass states are real modern states. They command authority, and a public arena within them is often well enough established that leaders are held accountable for poor public policies and performance. Unlike in cohesive-capitalist states, however, public authority in these states tends to be more fragmented and to rest on a broader class alliance - meaning that these states are not in a position to define their goals as narrowly or pursue them as effectively as are cohesive-capitalist states. Leaders of fragmented-multiclass states thus need to worry more about political support than do leaders of other types of developing country states. For example, they must typically pursue several goals simultaneously, as they seek to satisfy multiple constituencies. Industrialization and economic growth may be an important state goal, but it is only one among others: agricultural development, economic redistribution, welfare provision, and maintaining national sovereignty. Policy formulation and implementation, moreover, is often politicized, either because of intraelite conflicts or because state authority does not penetrate deep enough down in the society to incorporate and control the lower classes. When confronted by mobilized opposition, fragmented-multiclass states typically become obsessed with issues of legitimacy and often find themselves promising more than they can deliver. While not all fragmented-multiclass states are necessarily democracies, all developing country democracies with plebiscitarian politics and weak institutions constitute a special subset of fragmented-multiclass states. The cases of India and Brazil in several periods exemplify this type of state. Attempting to pursue a complex state-led agenda with limited state capacities, then, fragmented-multiclass states tend to be middling performers on numerous dimensions, including the promotion of industrialization and growth.

State Types and Patterns of Industrialization: If authority structures in the developing world can be variously categorized as neopatrimonial, cohesive-capitalist, and fragmented-multiclass states, the first 'big' question that $S D D$ analyzed 
was how these states influence economic outcomes. The nearly exclusive focus in the literature on appropriate policy choices is incomplete, even misleading. Policy choices matter, of course, but these choices must be explained. More important, the impact of the same policy applied in two different settings may vary because of the contextual differences. Identifying variations in how states are organized and in the institutionalized relationship of the state to the private sector is a key to understanding the relative effectiveness of state intervention in the economy. In the cases examined in detail in SDD (South Korea, Brazil, India, and Nigeria), this relationship varies along a continuum stretching from considerable convergence in goals to mutual hostility between the state and the private sector. I argue that, other things being equal, the setting that has proved to be most conducive (i.e., serves as a necessary but not a sufficient condition) to rapid industrial growth in the developing world is one in which the state's near-exclusive commitment to high growth coincided with the profit-maximizing needs of private entrepreneurs. The narrow ruling coalition in these cases was a marriage of repression and profits, aimed at economic growth in the name of the nation. Cohesive-capitalist states have generally created such political economies. Turning their countries into state-guided corporations of sorts, they have tended to be the fastest growers in the developing world.

Growth-oriented cohesive-capitalist states pursued their commitment to high growth by developing trade and industry with well-designed, consistent, and thoroughly implemented policies. Specific policy measures varied but were generally aimed at easing supply-and-demand constraints faced by private entrepreneurs. Some of these interventions were direct, and others, indirect. On the supply side, for example, we find that cohesive-capitalist states helped facilitate the availability of capital, labor, technology, and even entrepreneurship. Thus supply of capital was boosted at times by superior tax collection and public investment, at other times by using publicly controlled banks to direct credit to preferred private firms and sectors, and at yet other times by allowing inflation to shift resources from both agriculture and urban labor to private industrialists. Repression was also a key component in enabling private investors to have a ready supply of cheap, "flexible," and disciplined labor. Examples of less-direct interventions on the supply side include promotion of technology by investing in education and research and development, and/or by bargaining with foreign firms to enable technology transfer.

On the demand side, too, cohesive-capitalist states have pursued a variety of policies to promote their growth commitment. These have included expansionist monetary and fiscal policies, and tariffs and exchange-rate policies aimed at boosting domestic demand. And when domestic demand was not sufficient, these states have just as readily adopted newer policies that shift the incentives in favor of export promotion or, more likely, that help promote production for both domestic and foreign consumption.

Despite significant variation in the specific policy measures undertaken by 
cohesive-capitalist states, most policies adopted by cohesive-capitalist states reflected a single-minded and unyielding political commitment to growth, combined with a political realization that maximizing production requires assuring the profitability of efficient producers but not of inefficient ones. Sometimes this required getting prices right, but just as often it required "price distortions," such as undervaluing exchange rates, subsidizing exports, and holding wages back behind productivity gains. Cohesive-capitalist states in successful industrializers have thus been pragmatically - and often ruthlessly - procapitalist, much more than they have been purely and ideologically promarket.

Perfect coincidence between the goals of the state and those of private elites has been rare in the developing world, depending as it does on the difficult-to-acquire political precondition of cohesive state power and a narrow alliance between the state and capital-owning elites. Instead, many ruling elites governed states with fragmented political institutions and defined the public good more broadly. The elites pursued (or, at least, debated) several crucial goals simultaneously: economic growth, redistribution, legitimacy, and national sovereignty. Policy intervention in these fragmented-multiclass states was aimed not only at promoting growth but also at enhancing legitimacy and short-term welfare provision.

Mixed political goals of fragmented-multiclass states had several consequences for choosing and pursuing development policies. First, ruling elites were less focused in these cases on assessing state intervention strictly from the vantage point of growth consequences. Diffuse goals, in turn, enabled various groups and individuals to capture state resources for short-term, consumption-oriented benefits. Second, the relationship of the state to the private sector in such contexts was considerably more complex than in cohesive-capitalist states, sometimes cooperative but just as often conflictual. And third, both policy-making and implementation were more politicized, diluting their unidirectional effectiveness.

Fragmented-multiclass states are thus actually more "normal" than the other two ideal-typical cases being discussed here. But because the choice of economic strategy and of policy tools in these cases reflected the logic of both growth and politics, the institutional setting of fragmented-multiclass states was seldom conducive to achieving hypergrowth in industry. The case of India supports such a general contention, as do the cases of Brazil and South Korea in select periods.

Let us consider specific examples of the political economy dynamics of fragmented-multiclass states. Fragmented-multiclass states were neither more nor less interventionist than cohesive-capitalist states, but they were generally less effective at alleviating the supply-and-demand constraints faced by their investors. Again, for example, when it came to mobilizing capital in many fragmented-multiclass states, tax- collecting capacities were limited, public-spending priorities included numerous goals other than growth promotion, attempts to direct credit easily evolved into cronyism, and inflation as a tool of resource transfer could readily become a liability for political leaders concerned about their legitimacy. Periodic 
hostility on the part of the state elite toward private investors made the latter, both domestic and foreign, reluctant to invest. Repression of labor was also not a ready alternative in fragmented-multiclass states, thus making it difficult for investors to mobilize a cheap and docile labor force.

On the demand side, monetary and fiscal policies seldom reflected a consistent growth commitment but fluctuated instead with political cycles characterized by greater or lesser legitimacy. And finally, tariff and exchange-rate policies adopted to protect the national economy, and thus to promote demand for indigenous goods, often created powerful interest groups. As these groups were difficult to dislodge, fragmented-multiclass states found themselves more rigidly committed to a particular development path. In sum, fragmented-multiclass states, like cohesivecapitalist states, sought to promote industrialization, but they did so less effectively because their goals were more plural and their political capacities less developed. In other words, varying patterns of state authority decisively influenced developmental trajectories.

According to this line of argument, the worst setting for industrialization on the periphery was the states that had no clear public goals and whose leaders reduced the state to an arena for personal aggrandizement. These neopatrimonial states have unfortunately constituted a significant subset of the developing world. State intervention in these cases has often been motivated either by the need to build short-term political support via patronage or by personal greed - or sometimes by both. The relationship of the state and the private sector in such contexts has just as often been mutually corrupt: Political instability, inconsistent policies, and pilfering of public resources for personal and sectional gains have all hurt state-led efforts to promote industry and growth. The case of Nigeria provides a striking instance of such a development path, though elements of the same are also evident elsewhere.

Neopatrimonial states, like cohesive-capitalist and fragmented-multiclass states, intervened heavily in their economies - but with disastrous results. Neopatrimonial states often emerged in societies with weak private sectors, but instead of strengthening the private sector, these states appropriated scarce economic resources and diverted them everywhere but toward productive investment. Inconsistent economic policies, failure to support indigenous capitalists, poor-quality but activist labor, and political instability all reinforced the existing weakness of the national private sector in manufacturing and industry.

Given this profound weakness of domestic capitalism, neopatrimonial states sought to undertake economic activities directly or invited foreign goods and producers to fill the vacuum. Given the state's nondevelopmental proclivities and organizational weakness, efforts to produce goods in the public sector generally failed. The remaining alternative of importing goods or attracting foreign investment only makes sense if there are alternative sources of income and demand. For a country like Nigeria, oil exports provided a ready source of income and demand, 
which was met by foreign goods and producers; this is less true for other neopatrimonial states. Commodity booms, however, seldom last forever. The political incapacity to anticipate such cycles, plan for them, and cut back on imports and public expenditures when circumstances so demand further aggravate the tragedies of commodity-dependent neopatrimonial states. Given such state weakness, the question remains, is there a way out of these repetitive cycles of developmental disasters in neopatrimonial states?

Patterns of State Construction: If goals and capacities of the state, especially as they are expressed in the institutionalized relationship of the state and the private sector, are important for understanding relative effectiveness of state intervention, the next logical, though historically prior question, concerns the origins of this variation itself. Why have some parts of the developing world ended up with cohesive-capitalist states, others with neopatrimonial states, and yet others, probably the majority, with fragmented-multiclass states? This question forces the analysis to take a more historical turn.

While the answer to this question that I develop in SDD is mainly historical, two theoretical sensibilities shape the analysis. First, institutions are social patterns that only gel over time and, once gelled, they often endure beyond the forces that brought them into being. And second, what is true for all institutions is even truer for states because of collective action problems involved in organizing and reorganizing power and coercion on a national scale. As a result, basic state forms in the developing world emerged mainly via a series of infrequent big bangs. The impact of colonialism on state formation was especially significant because most developing countries states are the product of colonialism, and their respective forms were molded decisively by this encounter, with lasting consequences. Two extreme historical examples will illustrate this general point.

South Korea's cohesive-capitalist state, for example, originated during Japanese colonial rule, which differed in important respects from the colonialism of the European powers. As late developers, the Japanese made extensive use of state power for their own economic development, and they used the same state power to pry open and transform Korea within a relatively short period of time. The Japanese colonial impact was thus intense, brutal, and deeply architectonic. Three patterns of what eventually became South Korea's cohesive-capitalist, growth-promoting state originated in this period: a relatively corrupt and ineffective agrarian bureaucracy was transformed into a highly authoritarian and penetrating political organization; the state established close and working production-oriented alliances with the dominant classes; and a well-developed system of state control of the lower classes was created. Over time, as one would expect, these structures were battered by numerous new forces and some significant changes ensued. Nevertheless, the core state-class characteristics endured, eventually providing South Korea with a framework for the evolution of a high-growth political economy.

By contrast, British colonialism in Nigeria created a highly distorted state that 
readily evolved into a neopatrimonial and ineffective set of political organizations. Britain ruled Nigeria on the cheap, expending as little energy as possible. Within the shell of a modern colonial state and cloaked in the ideology of indirect rule, the British essentially utilized various "traditional" rulers to impose order. At its core, colonialism in Nigeria thus reinforced a pattern of patrimonial and personalistic rule that failed to centralize authority, to develop an effective civil service, and relatedly, to develop even such minimal political capacities as the ability to collect direct taxes. The public realm that came into being was barely demarcated from private and sectional interests in terms of both culture and organization. After the Second World War, when the colonial state's access to resources grew and the state became more and more involved in the economy, these distorted beginnings were further accentuated, as the state became further enmeshed in particularistic and personalistic networks. The political elite of sovereign Nigeria were never able to overcome the original deficiencies of state construction. They simply went from crisis to crisis, both controlling and wasting the society's scarce developmental resources.

The bald emphasis on colonialism as a determinant of state forms in the developing world of course needs to be qualified. Not all the cases examined in the study fully fit the argument. The Indian case, for example, more or less fits the argument but, of course, a popular and powerful nationalist movement was a critical influence on the development of the postcolonial state in that country. Nevertheless, Indian nationalists altered the inherited state less than often meets the eye, and the nature of India's nationalist movement was itself not unrelated to the character of British colonialism in India. By contrast, because formal colonialism ended rather early in Latin America, the argument does not readily apply to a country like Brazil. Even in Brazil, however, colonialism and other external influences cast a long political shadow. For example, the power of landed oligarchs, a weak central government with a patrimonial bureaucracy, and the prevalence throughout the country of decentralized and despotic political units that rested on patronage and private use of force were characteristics acquired during the colonial period - characteristics that lingered for at least a century after decolonization and even beyond. This legacy was overcome, and even then only partially, in the 1930s. The cohesive-capitalist state of Brazil, moreover, both during Estado Novo (19371945 ) and subsequently under military rule (1964-1984), was dominated by a settler colonial elite and supported by the armed forces. It drew inspiration, if not direct support, from the outside, that is, from European fascist states in the 1930s and subsequently from the U.S.-supported anticommunist, national security doctrines. On the whole then, state institutions inherited from the colonial past have proved to be "coins that do not readily melt." Political and social developments of the first half of the twentieth century were thus the mold for the shape and the functioning of developing country states in the second half of the century.

Power for Development: Power is the currency states use to achieve their desired ends. Power may be more or less legitimate, and it may be used positively as 
incentives or negatively as punishment or threat of punishment. The fact that some states have been more successful than others at propelling industrialization suggests that successful states possessed a greater degree of power to define and pursue their goals. Which factors contribute to developmental power in the hands of states is thus a theoretical theme that runs throughout $S D D$, a set of concerns that may also be usefully summarized in this overview.

Political analysts often think of power in distributional terms: who has it and who does not. Power in this way of thinking has a zero-sum quality, because, it is believed, the more power some have in society, the less others will have. Given a liberal preference for a more even distribution of power, this mode of conceptualizing power leads directly to comparisons of democracy with authoritarian governments, with a marked normative preference for the former over the latter. I share this normative preference and will return to some related issues in the conclusion. An exclusive emphasis on distribution of power, however, is not very helpful analytically for understanding variations in state capacity to achieve economic goals, mainly because it detracts attention from conceptualizing power as a resource that - like wealth - also grows or withers. Some authoritarian governments are more efficacious at wielding power than other authoritarian governments; the same may be true of democratic states. State capacities thus do not vary as a simple function of whether a government is more or less democratic. It is not surprising that research efforts aimed at clarifying whether democratic governments are better than authoritarian governments at facilitating economic growth have remained largely inconclusive.

A full understanding of why some states are more efficacious than others at facilitating industrial transformation has to be centered around a concept of power as a societal resource that varies in quantity and can thus grow or decline. Efficacious states simply have more power at their disposal than less efficacious ones: cohesive- capitalist states thus command a lot more power to define and pursue their goals than neopatrimonial states, with fragmented-multiclass states falling somewhere in between along the continuum. Key determinants of this variation in state power for development are organizational characteristics of state institutions, on the one hand, and the manner in which states craft their relations with social classes, especially producer classes, on the other hand.

More specifically, a narrow commitment to rapid economic development inclines cohesive-capitalist states to focus on a few critical tasks and to work closely with producer groups. A competent bureaucracy is generally essential to pursue these political goals, as well as to cement an alliance with business. Political and economic power thus reinforce each other and help to move the society rapidly toward state-defined goals. As noted above, a narrow alliance of state and business elites that hopes to run a country as if it were a corporation is difficult to hold together, mainly because others in society also demand representation. If left unchecked, such demands require a state's attention and resources and detract from 
its power to pursue its narrow growth goals. That is why cohesive-capitalist states tend to be authoritarian, often reaching deep down into the society to create wellstructured interest groups and thereby minimize political opposition. Since corporatism may create only a quiescent exclusion and thus may not add to the state's overall power, the more ambitious cohesive-capitalist states even attempt controlled ideological mobilization of popular groups - say, in the name of the nation - so as to also harness their energies to pursue state goals. Viewed from a liberal standpoint, such cohesive-capitalist states resemble fascist states of yore, and thus are not very desirable political forms. Nevertheless, it is these states that have succeeded in generating considerable power to pursue rapid industrialization in the developing world.

Neopatrimonial states, by contrast, tend to have a weak sense of public purpose, such that ideology does not play a very significant role. Pronouncements of public goals are usually cloaks for the pursuit of personal and sectional interests. The organizational underpinning of neopatrimonial states also tends to be underdeveloped: much of politics tends to be preclass, interest groups are often not well organized, and public bureaucracies lack competence and professionalism. Without a coherent ideology and effective organizations, neopatrimonial states lack developmental power and are rarely capable of defining and pursuing economic goals. Such economic growth as occurs in these settings therefore is likely to occur in spite of an ineffective state, rather than as a result of state action. Economic resources controlled by the state are instead likely to be put to corrupt use and end up in the hands of elites for private consumption, leading to failed efforts at state-led development.

Leaders of fragmented-multiclass states generally preside over states in which power is not highly concentrated, usually not so much because of a deliberate democratic design as because of weak political institutions that encourage intraelite divisions and limit a state's downward authoritative reach in the society. These leaders are generally also committed to a broad set of goals, and a variety of interest groups within these states make their demands known to the ruling elite. As noted above, given the competing goals they face, these legitimacy-sensitive elites work closely with business only on some issues and only some of the time. Since political and economic elites may often work at cross-purposes and since the demands of numerous other groups may also require attention, power resources of fragmented-multiclass states are often dissipated and there is an upper limit on how rapidly they can propel industrialization. Given continuous public scrutiny of leaders in such settings, however, there is also a lower limit on how corrupt and ineffective the elite can get. Within these upper and lower limits, the nature and the quality of public institutions can vary a fair amount - as can state performance. For example, institutions like ruling political parties may be well organized, enabling elites to prioritize their goals and pursue them consistently. Public bureaucracies may also vary in their skills and professionalism, thus helping to account for 
further variation in a state's capacity to implement economic policies. While a variety of fragmented-multiclass states may be politically more desirable because, even when authoritarian, they are more responsive to the demands of their citizens, when it comes to state-led economic development, they command limited power resources and generally tend to be middling performers.

To sum up, $S D D$ is a study that probes the role of the state as an economic actor )in select developing countries by analyzing both the patterns of state construction and the patterns of state intervention aimed at promoting industrialization and economic growth. For the purposes of this paper, a central message of $S D D$ is this: success or failure at economic development is associated more with the kind and less with the degree of state intervention.

\section{STATES AND DEVELOPMENT IN THE ERA OF “GLOBALIZATION”}

The case for the developmental importance of states that I make in $S D D$ is limited in terms of both time frame and issues to which it applies: it is based mainly on experiences prior to the neoliberal era, and the focus is more on growth than on distributional concerns. How well might the argument apply in the context of "globalization"? Also, what happens to the argument if the primary focus was not growth but distributive issues? I argue below that strong states will remain essential for negotiating the globalized world and for reconciling growth with distribution

Let us first consider the issue of 'globalization.' Much too much has been written on the subject, most of it quite ideological. What are some of the main recent changes in the global context of developing countries that might lead us to reconsider the state's developmental role? As far as patterns of transnational economic patterns are concerned, scholars like Barbara Stallings (1995), Robert Wade (1996), and Joseph Stiglitz (2002) have unpacked the concept of globalization carefully; they have clarified that what has truly changed in the era of globalization (say, post-1981) is the much greater availability and thus the importance of finance capital. By contrast, the growth in economic interactions across nations along such other dimensions as trade, direct foreign investment, and technology transfers has been more incremental. The neoliberal economic claim has been that these economic changes - whether dramatic or incremental - further necessitate minimal states and open economies in the developing world. Unfortunately for neoliberals, the evidence to support this claim is simply not available: the economic performance of countries that have ardently embraced neo-liberalism over the last couple of decades (say, in Latin America and sub-Saharan Africa) has often been less than satisfactory; and conversely, states have remained interventionist in cases that have grown handsomely (e.g., China, India and Vietnam).

The World Bank's recent study (2005) is useful for getting a full sense of recent 
development experiments in the "globalized" world. As the Bank documents, many Asian economies have done rather well since 1990, but sustained high growth has eluded much of Latin America and Africa (some exceptions are Chile, Tunisia, Botswana, and Mauritius). The Bank is thus led to acknowledge that "some countries managed to sustain rapid growth with just modest reforms, and others could not grow even after implementing a wide range of reforms" (p. xii). Slow growth in OECD countries was also not the main culprit because exports from developing countries grew rapidly during the 1990s, real interest rates remained low, foreign investment flows were large, and debt obligations claimed fewer resources (p. 9). The main drama of success and failure was thus within national political economies. And this drama, according to the Bank, was not so much "correct" or "incorrect" set of policies, as it was the institutional context within which policies were pursued (p. 10). While the Bank shies away from advocating strong and effective states as the key to development, it now admits that "government discretion" will remain essential "for a wide range of activities that are essential for sustaining growth" (p. 14).

With the role of institutions in general - and that of the state more specificallyremerging as central to the development discourse (Rodrik, 2006; UNCTAD, 2006), many of the old orthodoxies are crumbling. Notice some of the more important conclusions reached by the Bank itself: fiscal deficits may have some important dynamic consequences (p. 11-12); trade integration can be achieved even while maintaining relatively high rates of tariffs in the early stages of integration (p. 12); the risks of financial integration had been under-estimated and its gains over-estimated (p. 15); and much too much was expected from privatization (p. 20). Oh, how the world turns! One of the Bank's central messages by 2005 was that "different policies can yield the same result, and the same policy can yield different results, depending on country institutional context" (p. 12). Compare this with one of my main conclusions in SDD in 2004: "the impact of the same policy applied in two different settings may vary because of the varying political and institutional conditions in which economic policies are chosen and pursued" (p. 12).

These converging conclusions across very different scholarly tendencies suggest that improving the quality of state and other institutions will remain a precondition for improving economic outcomes in many developing countries. Of course, we know very little about how to improve institutional quality, but then we also know very little about how to improve growth and well being in the developing world. What we know is that, if you want to get on a path of sustained high growth, it is essential to create conditions that help accumulate capital, invest capital efficiently, and that facilitate upgrading of technology, including human capital. The role of the state will remain essential in both diagnosing and in helping unplug varying bottlenecks that hamper capital accumulation, efficient allocation of resources, and technological progress. If the state itself does not function properly, some prior state 
reforms that require deeper political changes may well be a precondition of sustained economic progress (Bresser-Pereira, 2008).

Is my central message then that, globalization or no globalization, states seeking rapid growth should continue to learn from such statist success stories as that found in East Asia? No. While the central message moves in that direction, some important qualifications need to be added. The East Asian model (to the extent that there is even such a thing) is neither easily emulated, nor always desirable (just notice the high political costs many countries of that region paid and are still paying). More important, the world has indeed changed in important ways since the likes of Park Chug Hee presided over rapid growth; by now, state-led capital accumulation for steel and ship building may not be easily replicated by others. Among the important global changes, the following are especially consequential for the developing world's efforts at deliberate development: the pressures toward democracy make it difficult to recreate cohesive-capitalist states; norms and rules of WTO make it difficult to subsidize export promotion; it would be foolish not to take advantage of equity capital that has become available in global markets; the role of the service sector has been growing in most developing country economies (Evans, 2007); prospects for a variety of South-South cooperation are growing; and, of course, the Cold War is now but a memory, with a muscular United States pressuring numerous developing countries to fall in line in one arena or another. So, I am not suggesting that globalization is irrelevant. What I am suggesting instead is that the globalization discourse creates an erroneous sense of discontinuity that needs to be tempered. Let me further support this point by referring to the important example of the recent economic rise of India.

There is nothing that many neo-liberal scholars would like more than to fit the story of India's economic rise as a successful example of their prescriptions. I have argued recently, however, that such an analysis of India is quite misleading (Kohli, 2006A, 2006B, 2007A). India's economic growth accelerated around 1980, well before India adopted some liberalizing reforms in 1991. Over the last twenty five years India has indeed liberalized its domestic economy and slowly opened it to the outside world. However, India is hardly a neo-liberal model. India brought down tariffs only slowly, limited foreign investment to certain sectors, continued to maintain fairly strict controls on capital movements, hardly undertook much privatization, and the size of government deficits have remained large, much too large by IMF's standards of what is prudent. What truly explains India's growth acceleration then is the growing cooperation between the Indian state and big business for growth and for controlling labor. There is more than a shade of East Asia here. The Indian state has remained interventionist, opening some sectors as deemed desirable (such as information technology), but regulating others (such as automobiles), where it was deemed necessary that domestic manufacturing capacity had to be protected against any sudden opening to either imports or to foreign investors. While much more can be said on these issues, if growth is the main concern, India 
represents a case par excellence of what a democratic developmental state might look like in the new era of globalization.

All my comments so far have focused on the state's role in promoting economic growth. I am deeply aware that economic growth is not the same thing as development. Economic growth is critical for development, including for poverty alleviation, but much more goes into balanced development, especially more equal distribution of the fruits of growth. So, what are the implications of the developmental state argument for distributive issues? I am afraid the implications are uncomfortable. While both growth promotion and redistribution require strong states, the type of state that is best suited to promote growth may not be as suited for facilitating redistribution.

A fairly obvious point that is worth reiterating is that there is no substitute for state action in such redistributive tasks as asset redistribution, making growth more inclusive (e.g., employment generating), promoting investments in public education and health, and in providing welfare nets. What types of states are most likely to pursue such distributive goals? Based on a comparative study of Indian states, I have argued elsewhere that well organized social-democratic states are most effective at pursuing redistributive tasks (Kohli, 2007b). Others have made a similar argument for the developing world as a whole, while taking into account constraints imposed by globalization (Sandbrook et al., 2007). Rare though effective social-democratic states are in the developing world, what they demonstrate is that redistribution of growth requires mobilized lower classes and well organized parties in power that are able to represent the interests of such classes. So, a central tension emerges: promotion of economic growth requires right-leaning strong states, but redistribution requires strong states of the left.

How is this tension to be resolved? While this is not easy, two comments are necessary. First, these are not the types of tensions that are resolved by scholars or by development practitioners. These tensions get played out instead in the world of real politics. Given democracy, some periodic alternation of power between parties of the left and the parties of the right may be the best hope to pursue both growth and redistribution, if not simultaneously, then at least cyclically. What both types of parties will need when they come to power, however, are well functioning states that can influence economic outcomes. And second, one should not exaggerate the tension between the parties of the left and the parties of the right in the post-Cold War era. Most social democratic parties remain concerned about growth (at times too much; notice the 'moderate left' in Latin America), and even parties committed to growth, such as in contemporary India, feel the need to invest in the promotion of education and health. And yet, to continue with the Indian example, even a commitment at the apex is not likely to lead to real changes without improving the quality of local governments; state reform will remain a prerequisite.

To conclude, the discussion above has been fairly sweeping. The main point has been to convey that states have been and are likely to remain of central impor- 
tance in facilitating growth and distribution in the developing world. Beyond such generalities, however, it is important to get specific very quickly: the problems of growth and distribution are very different in an India from that of Brazil, not to mention in a Nigeria. Committed national leaders - with effective state machineries and with some room to maneuver in a global political economy - are likely to best understand and pursue solutions to developmental problems.

\section{REFERENCES}

AMSDEN, Alice (2007) Escape from Empire: The Developing World's Journey from Heaven and Hell, Cambridge, MA: The MIT Press.

. (1989) Asia's Next Giant: South Korea and Late Industrialization, Oxford: Oxford University Press.

BRESSER-PEREIRA, Luiz Carlos (2008) “Macroeconomics of Stagnation and New Developmentalism in Latin America", in Forstater, Mathew and L. Randall Wray (eds.) Keynes for the Twenty-first Century. New York: Palgrave MacMillan: 145-174.

EVANS, Peter (2007) "In Search of the 21st Century Developmental State” unpublished.

(1995) Embedded Autonomy: State and Industrial Transformation. Princeton: Princeton University Press.

JOHNSON, Chalmers (1982) MITI and the Japanese Miracle, California: Stanford University Press.

KOHLI, Atul. (2006a) “Politics of Economic Growth in India, 1980-2005, Part I," Economic and Political Weekly, April 1, 2006.

. (2006B) “Politics of Economic Growth in India, 1980-2005, Part II," Economic and Political

Weekly, April 8, 2006.

. (2007a) "State and Redistributive Development in India," unpublished ms.

. (2007b) "State, Business, and Growth in India," Studies in Comparative International Development, June 2007: 87-114.

.(2004) State Directed-Development: Political Power and Industrialization in the Global Periphery, Cambridge: Cambridge University Press.

RODRIK, Dani (2006) “Goodbye Washington Consensus, Hello Washington Confusion,” unpublished ms.

SANDBROOK, Richard, et.al. (2007) Social Democracy in the Global Periphery, Cambridge: Cambridge University Press.

STALLINGS, Barbara (1995) Global Change, Regional Response, Cambridge: Cambridge University Press.

STIGLITZ, Joseph (2002) Globalization and its Discontents. New York: W.W. Norton and Company. UNCTAD (2006) Trade and Development Report, United Nations Publications.

WADE, Robert (1990) Governing the Market, Princeton: Princeton University Press. - (1996) "Globalization and its Limits: Reports of the Death of the National Economy are Greatly Exaggerated," in Suzzane Berger and Ronald Dore, eds., National Diversity and Global Capitalism, Cornell University Press, Ithaca, NY: Cornell University Press.

World Bank (2005) Economic Growth in the 1990s: Learning from a Decade of Reforms. 